\title{
Protein oxidation in mild essential hypertension
}

\author{
G. Caimi*, G. Mulè, E. Hopps, C. Carollo and R. Lo Presti \\ Dipartimento di Medicina Interna, Malattie Cardiovascolari e Nefrourologiche, Università di Palermo, \\ Italy
}

An intensified oxidative stress has been associated with aging and many disease, including essential hypertension (EH) $[6,11,16]$. In EH an increased level of reactive oxygen and nitrogen species (RONS) may impair the bioavailability of nitric oxide (NO), by inducing its accelerated transformation in peroxynitrite [4]. Beside this, many other pathophysiological processes in EH may be influenced by RONS, considering their harmful effects on the structural and functional properties of lipids, proteins and nucleic acids.

Some points need to be further investigated, such as the relationship between oxidative stress and the degree of hypertension, and identification of the most useful marker of enhanced oxidative stress in this clinical condition.

In EH several papers showed an increase in lipid peroxidation $[1,7,13]$; this datum was also present in juvenile essential hypertension [17] and in newly diagnosed hypertensives [12]. In other reports, however, normal levels of lipid peroxidation were observed $[5,8]$.

Fewer papers $[3,7,10,14]$ have examined protein oxidation in EH up to now. Among the indicators of protein oxidation, the most widely used is the concentration of protein carbonyl groups $(C=\mathrm{O})$. These groups are generated by oxidation of protein side chains, and some aminoacidic residues, such as lysine, proline, arginine and threonine are the most involved [15].

In this study we examined protein oxidation expressed as plasma protein carbonyl groups in untreated subjects with mild essential hypertension.

We enrolled 23 subjects (17 men and 6 women; mean age $45.05 \pm 6.14$ years; range $31-53$ years). The diagnosis of hypertension was based on blood pressure (BP) measurements taken on two separate occasions with the patient in a seated position after 15 minutes of rest. The mean values of these measurements were $144 / 87 \mathrm{mmHg}$. Only a minority of the patients showed a simultaneous increase of systolic and diastolic BP above 140/90 $\mathrm{mmHg}$, the great majority having only either systolic or diastolic values within the range of hypertension. In all patients an ambulatory BP monitoring was performed: day-time systolic BP and diastolic BP were respectively $134.2 \pm 8.4$ and $86.7 \pm 6.1 \mathrm{mmHg}$, night-time SBP and DBP were respectively $120.5 \pm 11.1$ and $75.7 \pm 7.5 \mathrm{mmHg}$ and $24-\mathrm{h}$ SBP and DBP were respectively $128.9 \pm 8.7$ and $82.4 \pm 5.7 \mathrm{mmHg}$. In this group the hypertension duration was $13.4 \pm 11.9$ months. The

\footnotetext{
${ }^{*}$ Corresponding author: Prof. Gregorio Caimi, Via del Vespro, 129 - 90127 Palermo, Italy, Tel.: +39 91655 4406, Fax: +39 91655 4535; E-mail: caimigre@unipa.it.
} 
basal glucose level was $91.95 \pm 11.04 \mathrm{mg} / \mathrm{dl}$, total cholesterol was $213.3 \pm 36.9 \mathrm{mg} / \mathrm{dl}$, LDL-cholesterol was $155.2 \pm 32.3 \mathrm{mg} / \mathrm{dl}$, HDL-cholesterol was $44.00 \pm 8.04 \mathrm{mg} / \mathrm{dl}$, triglycerides were $100.5 \pm 80.6 \mathrm{mg} / \mathrm{dl}$, serum uric acid was $5.85 \pm 1.65 \mathrm{mg} / \mathrm{dl}$. In hypertensives the body mass index (BMI) was $27.04 \pm 3.38$, the waist to hip ratio (WHR) was $0.913 \pm 0.049$.

The control group included 26 healthy subjects ( 17 men and 9 women; mean age $43.54 \pm 6.92$ years) recruited from hospital staff members and students. The basal glucose level was $87.54 \pm 8.79 \mathrm{mg} / \mathrm{dl}$, total cholesterol level was $207.5 \pm 33.0 \mathrm{mg} / \mathrm{dl}$, LDL-cholesterol was $145.5 \pm 28.01 \mathrm{mg} / \mathrm{dl}$, HDL-cholesterol was $44.65 \pm 7.43 \mathrm{mg} / \mathrm{dl}$, triglycerides were $86.77 \pm 35.22 \mathrm{mg} / \mathrm{dl}$, serum uric acid was $4.55 \pm 0.98 \mathrm{mg} / \mathrm{dl}$. The mean values of BP in these subjects were $120 / 71 \mathrm{mmHg}$. In this group BMI was $25.58 \pm 1.45$ and WHR was $0.917 \pm 0.041$.

The protein carbonyl group concentration was measured by an enzyme-linked immunosorbent assay (ELISA) kit (BioCell PC test kit, Enzo Life Sciences AG, Switzerland), which uses the reagent 2,4-dinitrophenylhydrazine (DNP). Plasma samples were incubated with DNP, and then plasma proteins were nonspecifically adsorbed to an ELISA plate. Unconjugated DNP and non-protein constituents were washed away. The adsorbed proteins were probed with biotinylated anti-DNP antibody, followed by streptavidin-linked horseradish peroxidase. A chromatin reagent was added, and the reaction was stopped by adding an acid solution. Absorbance for each well was measured at $450 \mathrm{~nm}$ and related to a standard curve prepared for serum albumin containing increasing proportions of hypochlorous acid-oxidized protein, calibrated colourimetrically. Total protein concentration in plasma samples was evaluated by the method of Lowry et al. [9].

Our data showed no statistical difference between normal controls and hypertensives regarding plasma protein carbonyl groups $(N=0.440 \pm 0.134 \mathrm{nmol} / \mathrm{mg}$ prot; Hypertensives $=0.459 \pm 0.136 \mathrm{nmol} / \mathrm{mg}$ prot $)$. In hypertensive and control subjects the carbonyl group concentrations were not related to age, BMI, WHR, metabolic parameters or blood pressure values.

Our datum is different from those observed by other authors who found an increase in plasma carbonyl groups in hypertensives, even though in a study hypertensive patients were much older [7] and in other studies patients had higher pressure values [3, 10, 14]. However, in the paper by Simic et al. [14], an increase of the carbonyl derivatives was found also in a few patients with grade 1 hypertension.

In a previous study [2], we observed an increase in lipid peroxidation, expressed as thiobarbituric acid reactive substance (TBARS), in a group of hypertensives including all the subjects evaluated in the present study. Although our study group is small, our data suggest that, in comparison with indices of lipid peroxidation, protein oxidation markers may appear later during the clinical course of $\mathrm{EH}$, and their evaluation at the early stages of the disease may underestimate the impact of oxidative stress in hypertensive patients.

\section{References}

[1] M.C. Armas-Padilla, M.J. Armas-Hernandez, B. Sosa-Chanache, R. Cammarata, B. Pacheco, J. Guerrero, A.R. Carvajal, R. Hernández-Hernández, Z.H. Israili and M. Valasco, Nitric oxide and malonildialdehyde in human hypertension, American Journal of Therapeutics 14 (2007), 172-176.

[2] G. Caimi, G. Mulè, E. Hopps, C. Carollo and R. Lo Presti, Nitric oxide metabolites and oxidative stress in mild essential hypertension, Clinical Hemorheology and Microcirculation 46 (2010), 321-325.

[3] M. Caner, Y. Karter, H. Uzun, A. Curgunlu, S. Vehid, H. Balci, R. Yucel, I. Güner, A. Kutlu, A. Yaldiran and E. Oztürk, Oxidative stress in human in sustained and white coat hypertension, Internal Journal of Clinical Practice 60 (2006), $1565-1571$ 
[4] R.A. Cohen and X.Y. Tong, Vascular oxidative stress: the common link in hypertensive and diabetic vascular disease, Journal of Cardiovascular Pharmacology 55 (2010), 308-316.

[5] J.L. Cracowski, J.P. Baguet, O. Ormezzano, J. Bessard, F. Stanke-Labesque, G. Bessard and J.M. Mallion, Lipid peroxidation is not increased in patients with untreated mild-to-moderate hypertension, Hypertension 41 (2003), 286-288.

[6] M.M. Elahi, Y.X. Kong and B.M. Matata, Oxidative stress as a mediator of cardiovascular disease, Oxidative Medicine and Cellular Longevity 2 (2009), 259-269.

[7] K. Kedziora-Kornatowska, J. Czuczejko, H. Pawluk, T. Kornatowski, J. Motyl, L. Szadujkis-Szadurski, K. Szewczyk-Golec and J. Kedziora, The markers of oxidative stress and activity of the antioxidant system in the blood of elderly patients with essential arterial hypertension, Cellular and Molecular Biology Letters 9 (2004), 635-641.

[8] A.M. Kuklinska, B. Mroczko, W.J. Musial, M. Usowicz-Szarynska, R. Sawicki, H. Borowska, M. Knapp and M. Szmitkowski, Diagnostic biomarkers of essential arterial hypertension, International Heart Journal 50 (2009), 341-351.

[9] O.H. Lowry, N.J. Rosebrough, A.L. Farr and T.D. Randall, Protein measurement with the Folin phenol reagent, Journal of Biological Chemistry 193 (1951), 265-275.

[10] H. Nandeesha, V. Sathiyapriya, Z. Bobby, P. Pavithran, A. Agrawal and N. Selvaraj, Altered oxidant-antioxidant status in non-obese men with moderate essential hypertension, Indian Journal of Medical Sciences 61 (2007), 326-331.

[11] K.B. Pandey and S.I. Rizvi, Markers of oxidative stress in erythrocytes and plasma during aging in humans, Oxidative Medicine and Cellular Longevity 3 (2010), 2-12.

[12] P. Pavithran, H. Nendeesha, V. Sathiyapriya, Z. Bobby and T. Madanmohan, Short-term feart variability and oxidative stress in newly diagnosed essential hypertnsion, Clinical and Experimental Hypertension 30 (2008), 486-496.

[13] R. Rodrigo, H. Prat, W. Passalacqua, J. Araya, C. Guichard and J.P. Bächler, Relationship between oxidative stress and essential hypertension, Hypertension Research 30 (2007), 1159-1167.

[14] D.V. Simic, J. Mimic-Oka, M. Pljesa-Ercegovac, A. Savic-Radojevic, M. Opacic, D. Matic, B. Ivanovic and T. Simic, Byproducts of oxidative protein damage and antioxidant enzyme activities in plasma of patients with different degrees of essential hypertension, Journal of Human Hypertension 20 (2006), 149-155.

[15] E.R. Stadtman, Metal ion-catalyzed oxidation of proteins: biochemical mechanism and biological consequences, Free Radical Biology \& Medicine 9 (1990), 315-325.

[16] R.M. Touyz and E.L. Schiffrin, Reactive oxygen species in vascular biology: implications in hypertension, Histochemistry and Cell Biology 122 (2004), 339-352.

[17] S. Turi, A. Friedman, C. Bereczki, F. Papp, J. Kovàcs, E. Karg and I. Németh, Oxidative stress in juvenile essential hypertension, Journal of Hypertension 21 (2003), 145-152. 